\title{
MICRALYMMA MARINUM (STROEM) IN NORTH \\ AMERICA: BIOLOGICAL NOTES AND NEW DISTRIBUTIONAL RECORDS (COLEOPTERA: STAPHYLINIDAE)*
}

\author{
By MARgaret $\mathrm{K}$. Thayer \\ Museum of Comparative Zoology and \\ Department of Organismic and Evolutionary Biology \\ Harvard University, Cambridge, Massachusetts 02138
}

Micralymma marinum (Stroem) is an amphi-Atlantic intertidal beetle whose wide distribution in the Old World is fairly well known (Lindroth 1931, 1957; Steel 1958), but its range in North America has not been well documented. LeConte (1863) described M. stimpsonii from the "coast of Maine." Lindroth (1931:206) regarded this species as merely a variety of $M$. marinum and Steel (loc. cit.) listed it as a synonym of the latter. This synonymy has not been listed in North American catalogues (Leng et al. 1933-1948, Moore and Legner 1975) or Arnett's manual (1968). After comparing the unique type of $M$. stimpsonii (a female) with the North American specimens listed below, a specimen from Iceland identified by Lindroth (also a female), and the illustrations (including aedeagus) provided by Steel (1958), I agree that $M$. stimpsonii is synonymous with $M$. marinum. The vague type locality of $M$. stimpsonii, further south than any European records, has been the only record of the species from the United States, and although Lindroth (1957: fig. 32) mapped records from northwest, south, and southeast Newfoundland and Steel (loc. cit.) mentioned seeing specimens from there, neither provided specific locality data. Since it appears that no specific New World locality records have been published for $M$. marinum, it seems worth presenting some recently acquired data, particularly since one recent record extends the known range of the species south to Massachusetts at latitude $42^{\circ} 25^{\prime} \mathrm{N}$. Two specimens collected by Palmén whose records were apparently included on Lindroth's map (1957: fig. 32) are among those listed.

Unless noted otherwise ("no ecol. data"), all of the specimens listed were collected on rocks or in rock crevices in the intertidal

*Manuscript received b! the editor Octoher 2, 1984 
zone (between high and low tide marks). The records are mapped in Figure 1. Specimens are in the collections of: American Museum of Natural History, New York [AMNH], California Academy of Sciences, San Francisco [CAS], Canadian National Collection, Biosystematics Research Institute, Ottawa [CNC], Field Museum of Natural History, Chicago [FMNH], Paul J. Johnson, Moscow, Idaho [PJJ], Museum of Comparative Zoology, Harvard University, Cambridge [MCZ], Memorial University of Newfoundland, St. John's [MUNF], University of New Hampshire, Durham [UNH], U. S. National Museum of Natural History, Washington [USNM], University Zoological Museum, Helsinki [ZMH], and the author and Alfred F. Newton, Jr., Cambridge [ANMT]. In the following records, $\mathrm{A}=$ adults and $\mathrm{LI}, \mathrm{LII}, \mathrm{LIII}=$ la arvae of each instar.

Canada: Newfoundland: Change Is., Aug. 1-9, 1981, lot 6, D. Larson [no ecol. data] (12A) [MUNF, ANMT]; Grand Bruit, S. Newfoundland, N:o 55, 18.6.1949, Ernst Palmén [no ecol. data] (1A) [ZMH]; St. John Island, St. John Bay, NW Newfoundland, N:o 195, 3.8.1949, Ernst Palmén [no ecol. data] (1A) [ZMH]; $2 \mathrm{mi}$ S St. Pauls, VIII-1-1972, J.M. Campbell (12A) [CNC, ANMT]; same locality, VIII-10-1972, J.M. \& B.A. Campbell (15A) [CNC]. QuebeC: Mont-St.-Pierre, VII-18-1972, J.M. Campbell (1A) [CNC]. United States: Maine: Lincoln Co., Monhegan Island, nr. Seal Ledges, 16.VII.1982, M. Thayer \& A. Newton (374A; 312L: $16 \mathrm{LI}$, 108 LII, 188 LIII) [AMNH, ANMT, CAS, CNC, FMNH, MCZ, MUNF, PJJ, UNH, USNM, ZMH]; Monhegan I., $\mathrm{N}$ of Calves Cove, 17.VII.1972, M. Thayer \& A. Newton (22A; 12L: 1 LI, 3 LIl, 8 LIII) [ANMT]; Monhegan I., Deadman's Cove, 17.VII. 1982, M. Thayer \& A. Newton (1 LII) [ANMT]; York Co., Isles of Shoals, Appledore Island, 28-29.V.1983, M. Thayer \& A. Newton (25A, 4 LIII) [ANMT, UNH]. MASSACHUSETTS: Essex Co., Nahant, nr. East Point, 10.VIII.1982, M. Thayer \& A. Newton (2A) [ANMT, MCZ].

A further collection, undoubtedly of $M$. marinum although $I$ have not seen the specimens, is: NEW HAMPSHIRE: Rockingham Co., Isles of Shoals, ne side of Star Island, 3 July 1981, on intertidal rocks, W. F. Gimpel, Jr., collector (W. F. Gimpel, Jr., personal communication).

There has been speculation about the natural food of $M$. marinum, but no field observations have been made. Laboulbène (1858) 


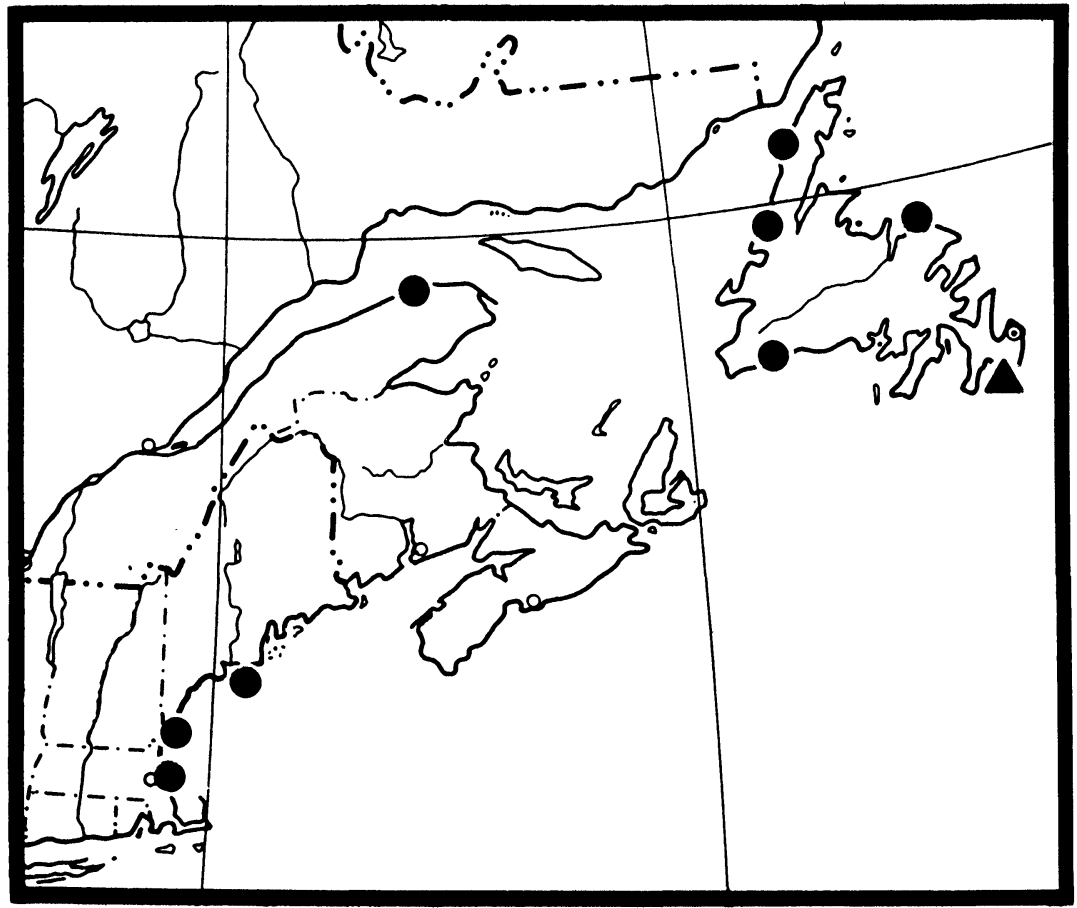

Fig. 1. Distribution of $M$. marimum in North America. Circles represent records given in text; triangle represents a record mapped by lindroth (1957), exact locality unknown.

mentioned finding with $M$. marinum abundant "Podurelles" (probably Anurida maritima (Guérin)), less abundant mites, and annelids and "petits coquillages." It is not clear whether the last refers to mussels, periwinkles, barnacles, amphipods, or something else. West (1930) said that $M$. marinum are "... considered probably to prey on Thysanura," but Lindroth (1931) regarded this claim (without giving any reference for it) as very unlikely because Thysanura are not known to occur at the Iceland $M$. marinum localities. Steel $(1958,1970)$ stated without giving reasons that "their main food appears to be the Collembolan Anurida maritima (Guérin)" (Poduridae or Hypogastruridae). In my collecting I saw very few of these Collembola, some small mites, many barnacles, and many small and 
large amphipods in the areas where $M$. marinum was common. All except barnacles seem likely as potential food for the beetles. Beetles (both adults and larvae) that I kept in culture fed avidly on freshlykilled adult Drosophila spp., and were apparently still healthy after up to three and one-half months of such a diet. One third-instar larva finished its larval development feeding on these flies and pupated successfully. Clearly Micralymma marinum are predators, but not obligate feeders on any element of their natural habitat; their usual natural food remains uncertain.

King et al. (1979) suggested on the basis of collecting in southern Wales (at ca. $\left.51^{\circ} 30^{\prime} \mathrm{N}\right)$ that $M$. marinum overwinter as eggs or as adults, hidden deep in rock crevices. Steel (1970) suggested on the basis of his collecting in southwestern England (at ca. $50^{\circ} 43^{\prime} \mathrm{N}$ ) and in Scotland (at ca. $57^{\circ} 00^{\prime} \mathrm{N}$ ) that adults overwinter and then lay eggs in May and June. One of the third-instar larvae I collected in Maine (at ca. $43^{\circ} 03^{\prime} \mathrm{N}$ ) in late May pupated on 2 July and when preserved on 15 July appeared to be only a few days from adult eclosion. It appears from the last that in Maine some of the beetles may overwinter as larvae, or that the life cycle may be longer than one year. Steel (1970) found that most British Omaliinae overwinter as larvae (Thayer 1985 found the same for the North American species Brathinus nitidus LeConte and Lesteva pallipes LeConte), but $M$. marinum certainly occurs in a different habitat from most Omaliinae and is undoubtedly subjected to different selective pressures. It is possible that the life cycle varies somewhat in different parts of the species' range.

With two exceptions, the morphological features discussed by King et al. (1979) and Elliott et al. (1983) in relation to the habitat of Micralymma marinum are all normal features of most or all Omaliinae. The aptery of $M$. marinum is unusual, though certainly not unique, within the subfamily. Its connection with the habits of the species is open to question, however, since the other species in the genus ( $M$. brevilingue Schi $\phi \mathrm{dte}, M$. caucasicum (Melichar)) are also apterous (Steel 1958, 1962) and $M$. marinum is the only one that is stricly marine intertidal (Steel 1962). Of perhaps more interest is the modification of the tarsal setae mentioned by both King et al. (loc. cit.) and Elliott et al. (loc. cit.). Micralymma marinum has, as they pointed out, flattened and widened ventral tarsal setae on the first four segments of all tarsi in both sexes. They are slightly more 
strongly modified in males than females, and those on the male protarsi are more distinctly flattened than those on the other tarsi. Most species of Omaliinae, if possessing flattened tarsal setae at all, have them only on the protarsi (sometimes also mesotarsi) of males (Thayer and Newton 1979; author's unpublished data), presumably aiding in grasping females during mating. The distribution of the specialized setae in $M$. marinum is very much like that found in omaliine genera whose adults are flower-inhabiting pollen feeders (Eusphalerum, Pelecomalium, Amphichroum, Austrolophrum, and Anthobiomimus). In both cases it seems to be an adaptation facilitating adhesion to the exposed surfaces on which the beetles occur (see Stork 1980, 1983), with the more pronounced development in males again presumably related to adhesion to females during mating.

King et al. (loc. cit.) mentioned the pupa of $M$. marinum as having "a number of long lateral setae ... which presumably also help in maintaining position" in rock crevices. These long projections (not actually setae) are found in all described omaliine pupae (Olophrum, Paulian 1941; Antarctotachinus, Jeannel 1940; Brathinus, Thayer 1985) and Microedus (author's unpublished data). Of these, all but Brathinus have pairs of similar projections paramedially on the abdominal tergites as well. (Laboulbène 1858 illustrated the pupa of $M$. marinum but apparently overlooked the dorsal projections.)

Lindroth $(1931,1957)$ proposed that Micralymma marinum originated in North America and that its trans-Atlantic distribution resulted largely through passive transport of beetles by the Gulfstream, attached to pieces of seaweed, driftwood, or other flotsam. This explanation does seem ecologically, physiologically, and meteorologically plausible (Laboulbène 1858 and Elliott et al. 1983, immersion tolerance data; Lindroth 1931 and 1957, map of Gulfstream), but another factor that must be considered in analyzing the historical biogeography of the species is its phylogenetic relationship to the other species of the genus: where might the common ancestor of $M$. marinum and its sister-species (or sister-group) have occurred? As this phylogenetic question has not yet been explored, the question of why Micralymma marinum is where it is must be regarded as only tentatively answered. 


\section{ACKNOWLEDGEMENTS}

This research was done largely during the tenure of a NSF Graduate Fellowship. I thank P. S. Thayer for accommodations on Monhegan Island, the Edwards Marine Science Institute of Northeastern University for access to the Nahant collecting site, and A. Borror (Shoals Marine Laboratory) for his hospitality and for permission to collect on Appledore Island. My thanks also go to J. M. Campbell (Biosystematics Research Institute, Ottawa) for the loan of CNC specimens of Micralymma; D. Larson (Memorial University of Newfoundland, St. John's) for his gift of specimens; $H$. Silfverberg (University Zoological Museum, Helsinki) for the locality information from Palmen's specimens; M. Huybensz for arranging the trip to Appledore and him and $\mathrm{M}$. Ormes for assistance in the field there; W. F. Gimpel, Jr. (Maryland Department of Agriculture, Annapolis) for information on the specimens he collected on Star Island; and P. J. Johnson (formerly MCZ-Harvard University, now University of Idaho, Moscow) for reading and offering helpful comments on the manuscript. Special thanks are due A. F. Newton (MCZ-Harvard University) for his enthusiastic help in collecting Micralymma as well as for reading and commenting on the manuscript.

\section{Literature Cited}

ARnftr, R. H. 1968. The beetles of the United States (A manual for identification). American Entomological Institute, Ann Arbor, xii + $1112 \mathrm{pp}$.

El.liott, P., KING, P. E., and Fordy, M. R. 1983. Observations on staphylinid beetles living on rocky shores. J. nat. Hist. 17:575-581.

Jrannel, R. 1940. Croisière du Bougainville aux îles australes françaises. III. Coléoptères. Mèm. Mus. natn. Hist. nat., Paris (N.S.) 14:63-201.

King, P. E., Fordy, M., and Al-Kualifa, M. S. 1979. Observations on the intertidal Micral!mma marinum (Stroem) (Col., Staphylinidae). Entomologist's mon. Mag. 115:113-136.

Laboulbìne, A. 1858. Sur les moeurs et l'anatomie de la Micralymma brevipenne. Ann. Soc. ent. Fr. (3):6:73-110. [later synonymized with Micralymma marinum]

LEConte, J. L. 1863. New species of North American Coleoptera. I. Smithsonian misc. Collections No. 167:240 pp.

Leng, C. W. And Mitchler, A. J. 1933. Second and third supplements (1925-1932) to Catalogue of the Coleoptera of America, north of Mexico, John D. Sherman, Jr., Mount Vernon, NY, 112 pp. Blackwelder, R. E. 1939. Fourth Supplement (1933-1938...146 pp. Blackwelder, R. E. and Blackwelder, R. M. 1948. Fifth supplement (1939-1947)...87 pp. 
Lindroth, C. H. 1931. Die Insektenfauna Islands und ihre Probleme. Zool. Bidr. Upps. 13:105-599.

1957. The faunal connections between Europe and North America. John Wiley and Sons, New York, $344 \mathrm{pp}$.

MoOre, I. AND Legner, E. F. 1975. A catalogue of the Staphylinidae of America north of Mexico. Div. agric. Sci., Univ. Calif., Spec. Publ. 3015, 514 pp.

Patilian, R. 1941. Les premieres états des Staphylinoidea. Mem. Mus. natn. Hist. nat., Paris 15:1-361.

Strel, W. O. 1958. Notes on the Omaliinae (Col., Staphylinidae). (9) The genus Micral!nma Westwood. Entomologist's mon. Mag. 94:138-142.

1962. Notes on the Omaliinae (Col., Staphylinidae). (11) The genus Micromalium Melichar, with further notes on Micralymma Westwood. Entomologist's mon. Mag. 97:237-239 (1961).

1970. The larvae of the genera of the Omaliinae (Coleoptera: Staphylinidae) with particular reference to the British fauna. Trans. R. ent. Soc. Lond. 122:1-47.

Stork, N. E. 1980. A scanning electron microscope study of tarsal adhesive setae in the Coleoptera. Zool. J. Linn. Soc. 68:173-306.

1983. The adherence of beetle tarsal setae to glass. J. nat. Hist. 17:583-597.

THAYER, M. K. 1985. The larva of Brathinus nitidus LeConte and the systematic position of the genus (Coleoptera: Staphylinidae). Coleopts. Bull. 39(2):174-184. AND Ni:Wton. A. F. JR. 1979. Revision of the south temperate genus Glypholoma Jeannel, with four new species (Coleoptera: Staphylinidae: Omaliinae). Psyche 85:25 63 (1978).

WIst, A. 1930. Coleoptera. Zoology of the Faroes 2(1), pt. 40:1-92, Copenhagen. 

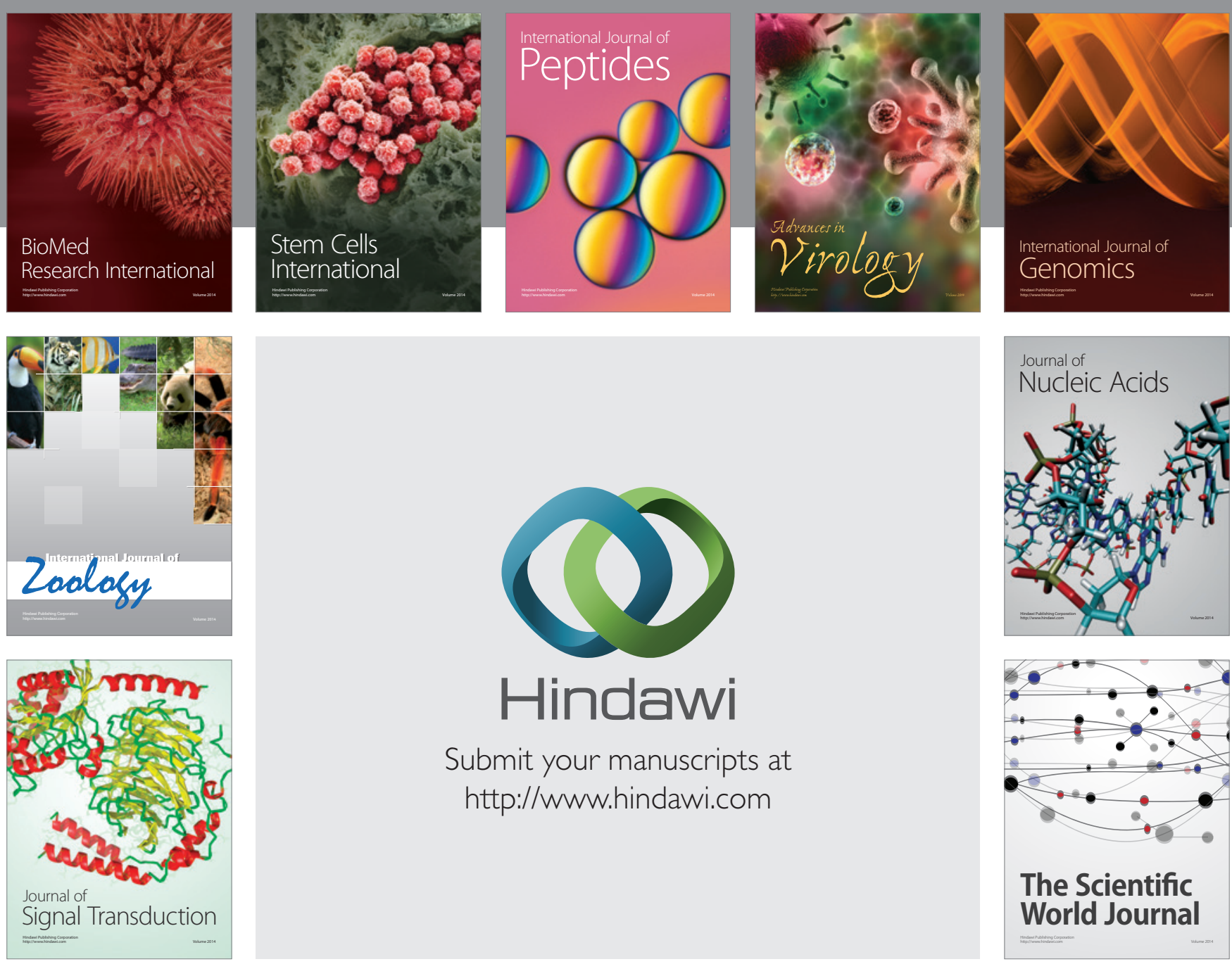

Submit your manuscripts at

http://www.hindawi.com
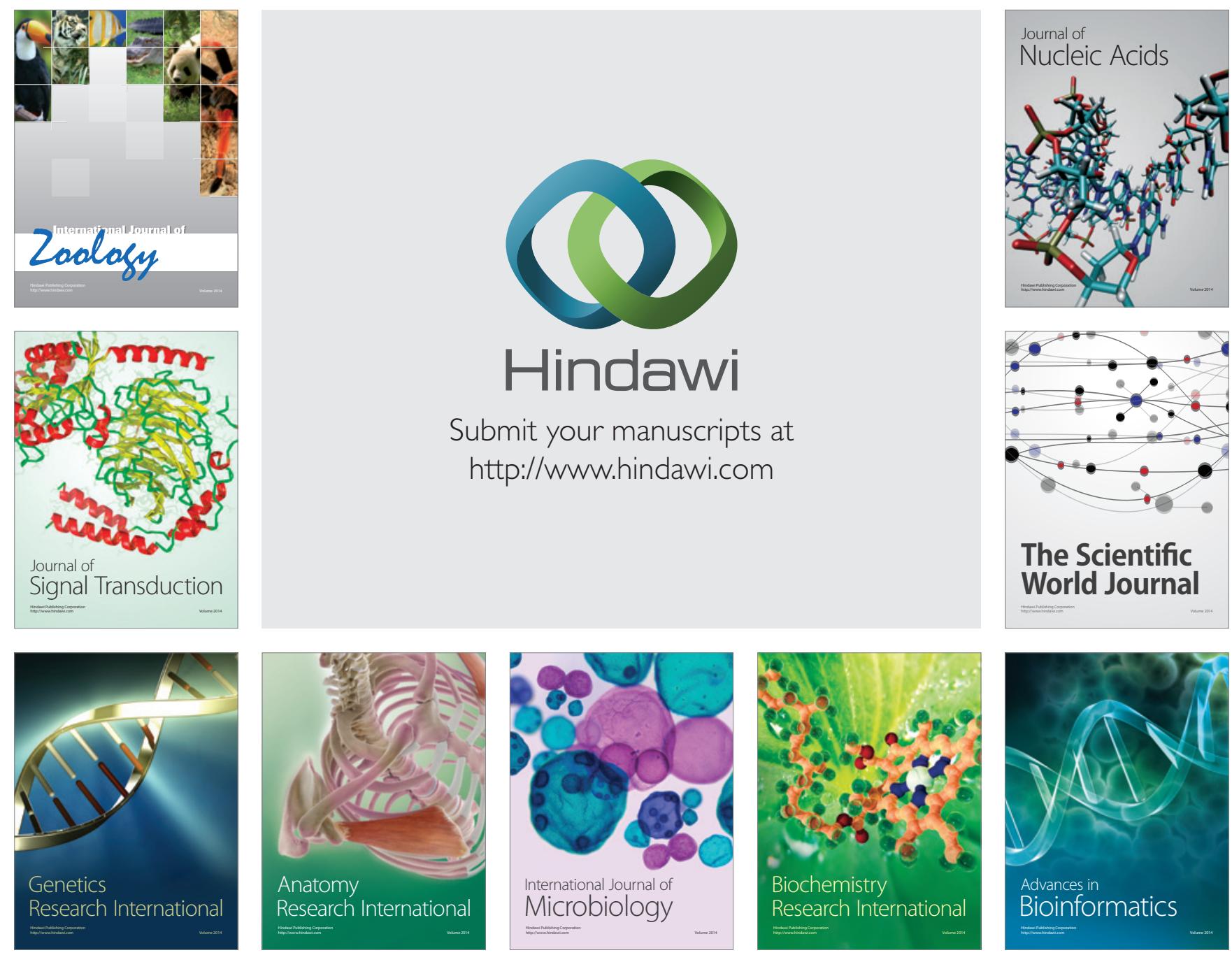

The Scientific World Journal
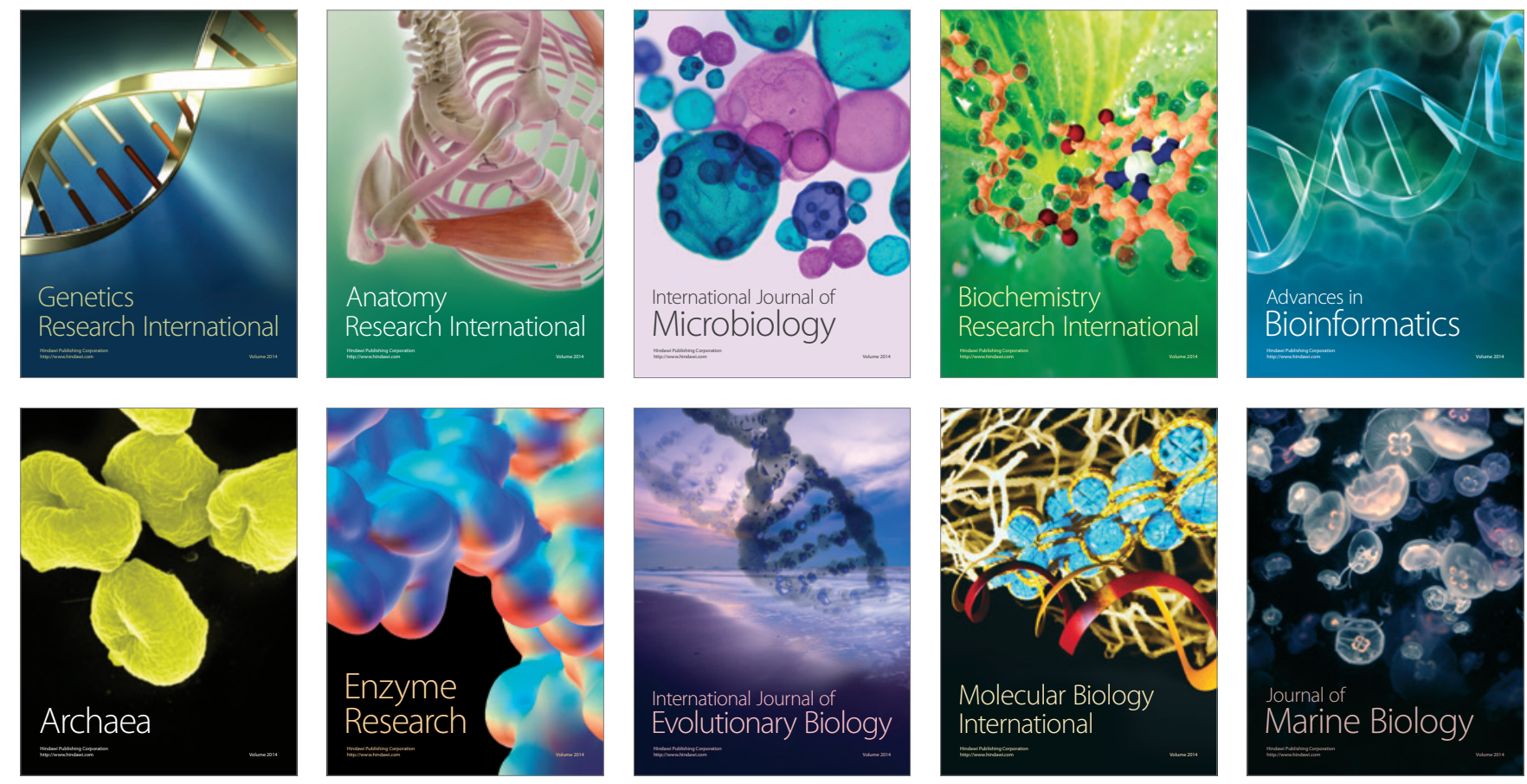